\title{
弾塑性地震応答における $\mathrm{P}-\Delta$ 効果と安定比 STABILITY RATIO AND DYNAMIC $P-\Delta$ EFFECTS IN INELASTIC EARTHQUAKE RESPONSE
}

\author{
山崎真司*, 遠藤和 明** \\ Shinji YAMAZAKI and Kazuaki ENDO
}

\begin{abstract}
A stability ratio was applied as an index expressing the $\mathrm{P}-\Delta$ effects in inelastic earthquake response. The stability ratio includes the characteristics of the vibration system and the amount of energy exerted by an earthquake. The $\mathrm{P}-\Delta$ effects in inelastic response cause the concentration of plastic strain energy into one side and the increase in ductility factor. The degree of the concentration and the increase can be estimated using the stability ratio as an index. The validity of this estimation method was verified by carrying out inelastic response analyses using SDOF models and MDOF models.
\end{abstract}

Keywords: $P-\Delta$ effect, stability ratio, energy response, cumulative plastic deformation ratio, ductility factor, stability limit state

$\mathrm{P}-\Delta$ 効果, 安定比, エネルギー応答, 累積塑性変形倍率, 塑性率, 安定限界状態

1. はじめに

$P$ - 効果についてはこれまで数多くの研究が行われている。 Bernal $^{1)}$ は完全弾塑性型の復元力特性を有する1質点系モデルに対し て、予め設定した塑性率となる降伏せん断力を $\mathrm{P}-\Delta$ 効果を考慮し た場合と無視した場合それぞれについて求め、その比を増大率とし、 増大率についての推定式を作成している。これに対し、兽我部、小 高2)は、Bernalと同様のモデルに対して、降伏せん断力を一定として、

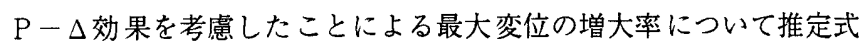
を提案している。

秋山音は、柱降伏型鋼構造剛接骨組について、P - $\Delta$ 効果を考慮 した場合と無視した場合の所要降伏せん断力係数の関係を表す式を 導いている。一方、鈴木等 ${ }^{4), 5}$ は、低層部にソフトストーリーを有す るコンクリート造多層骨組について、安定限界状態を保つ条件を導 いている。

石山、河上 ${ }^{6), 7)}$ は、完全弾塑性型の復元力特性を有する1質点系モ デルに対して地震応答解析を行い、構造特性係数 $D_{s}$ の大きさと $\mathrm{P}$ $\Delta$ 効果による崩壊の可能性との関係を調べている。板矢、松島息,99 は、 曲げせん断型多質点系モデルに対する地震応答解析を行い、 $\mathrm{P}-\Delta$ 効果の影響が無視できない条件について検討している。 上谷 ${ }^{10), 11)}$ は、梁降伏型多層多スパン平面骨組の動的崩壊過程にお
ける変形集中現象について理論的に明らかにし、地震応答解析によ り理論の検証を行っている。

本論文では、 $\mathrm{P}-\Delta$ 効果による歪エネルギーのひとつの方向への 偏りおよび塑性率の増加現象を推定するための指標として安定比を 導入する。安定比は、振動系の特性と入力の大きさとを含む指標で、 その有効性を1質点系および多質点系モデルに対する弾塑性応答解 析を行い検証する。

\section{2. 安定比}

図1の様な1質点系モデルを考える。ばねの荷重変形関倸は図2に 示寸様なBi-linear型で、耐力の低下は生じないものとし、塑性勾配 係数 $\alpha$ は以上とする。

$\mathrm{P}$ - $\Delta$ 効果を考慮した振動方程式は次式で表される。

$$
m \ddot{x}+c \dot{x}+Q-k_{p_{\Delta}} x=-m \ddot{x}_{0}
$$

ここで、

$m$ : 質量、 $c$ : 減衰係数、 $Q$ : ばねの反力、 $k_{P \Delta}: \mathrm{P}-\Delta$ 効果

による見かけの剛性低下、 $\ddot{x}_{0}:$ 地動加速度

$Q-k_{P \Delta} x$ がこの系の復元力である。 $k_{P \Delta}$ は次式で与えられる。

$$
k_{p \Delta}=m g / l
$$

* 東京都立大学大学院工学研究科建築学尃攻 教授.工博

** 日本設計 (元東京都立大学 大学院生) 修士(工学)
Prof., Dept. of Architecture, Graduate School of Engineering, Tokyo Metropolitan Univ., Dr. Eng.

Nihon Sekkei, M. Eng. 


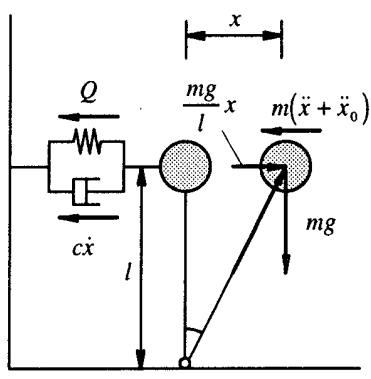

図1 1質点系モデル

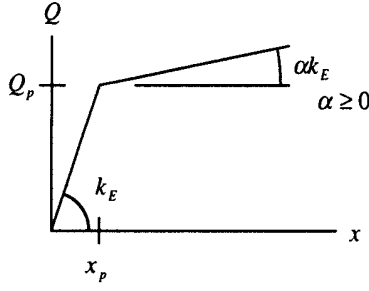

図2ばねの荷重変形関係
ここで、

$g:$ 重力加速度、 $l:$ 質点の高さ (図 1 参照)

$\mathrm{P}-\Delta$ 効果の指標として、次式で定義される安定係数 $\theta$ が用いら れている(1),12),13)。

$$
\theta=\frac{k_{p_{\Delta}}}{k_{F}}
$$

ここで、

$k_{E}:$ ばねの弾性剛性

ひとつの地震動に対して、この系に入力するエネルギーのうち、 損傷に寄与する量を $E_{D}$ とし、 $E_{D}$ を次式による累積蓋性変形倍率 $\eta$ で表わす。

$$
\eta=\frac{E_{D}}{Q_{p} x_{p}}
$$

$$
\text { ここで、 }
$$

$Q_{p}:$ ばねの降伏強度、 $x_{p}$ : ばねの降伏変位 (図2参照)

振動系は、その復元力 が0になったときをもって 崩壊とする。崩壊状態の ひとつとして、応答にお ける塑性変形增分が完全 に一方向のみに累積し、 地震終了時に復元力が0に なる場合を考える。図3に

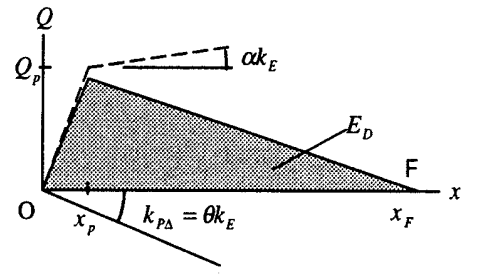

図3 崩壊状態
おいて、破線がばねの反力、実線が復元力 $\left(Q-k_{P \Delta} x\right)$ を表してい るものとすれば、上記の場合には、地霞終了時に復元力は図中のF 点に達している。このときの $\theta$ を $\theta_{c r}$ とする。吸収エネルギーは実線 と $x$ 軸で囲まれた面積であるから、このときの $E_{D}$ は次式で与えられ る。

$$
E_{D}=\frac{1}{2} Q_{p} x_{p} \frac{\left(1-\theta_{c r}\right)(1-\alpha)}{\theta_{c r}-\alpha}
$$

(4)、(5)式より、 $\theta_{c r}$ と $\eta$ の関係を表す次式が導かれる。

$$
\eta=\frac{\left(1-\theta_{c r}\right)(1-\alpha)}{2\left(\theta_{c r}-\alpha\right)}
$$

(6)式を $\theta_{c r}$ について解けば次式のようになる。

$$
\theta_{c r}=\frac{2 \eta \alpha+1-\alpha}{2 \eta+1-\alpha}
$$

安定比 $\tau$ を次式で定義する。

$$
\tau=\frac{\theta}{\theta_{c r}}
$$

(7)式を用いれば、 $\tau$ は次式で表される。

$$
\tau=\theta \frac{2 \eta+1-\alpha}{2 \eta \alpha+1-\alpha}
$$

$\tau$ は振動系の性質 $(\alpha$ および $\theta)$ と入力の大きさ $(\eta)$ からなる 指標で、振動系を固定して考えれば、入力の大きさを表す指標であ り、入力を固定して考えれば、 $\mathrm{P}-\Delta$ 効果剛性 $\left(k_{p \Delta}\right)$ の大きさを 表す指標である。 $\tau=1$ のとき、応答は必ずしも図3のF点の状態に達 するとは限らない。F点に達するのは塑性変形が完全に片側に偏っ た場合であり、一般には最大変位は図3の $x_{F}$ 以下となる。

ところで、損傷に寄与する入力エネルギー $E_{D}$ は次式に示す等価 な速度 $V_{D}$ を用いて表される。

$$
V_{D}=\sqrt{\frac{2 E_{D}}{m}}
$$

$V_{D}$ は、ひとつの地震動に対し、減衰定数と固有周期のみで決まる 量であることが知られている ${ }^{14)}$ 。

ここで、

$$
\begin{aligned}
& Q_{p}=m g C_{B} 、 x_{p}=\frac{Q_{p}}{k_{E}} 、 k_{E}=\left(\frac{2 \pi}{T}\right)^{2} m \\
& C_{B}: \text { せん断力係数、 } T: \text { 固有周期 }
\end{aligned}
$$

の関係を用いれば、(4)、(10)式より次式が導かれる。

$$
\eta=\frac{2 \pi^{2} V_{D}^{2}}{C_{B}^{2} g^{2} T^{2}}
$$

従って、安定比 $\tau$ は地震動の $V_{D}$ と対応づけることができる。

$\mathrm{P}-\Delta$ 効果が地震応答に及ほす影響を表す指標として $て か ゙$ 有効な ものであることを、次章以降に示す。

\section{1質点系モデルに対する解析}

\section{$3.1 P-\Delta$ 効果が弾塑性応答に与える影響}

ひとつの地震波による入力エネルギーは質量と固有周期で決まり、

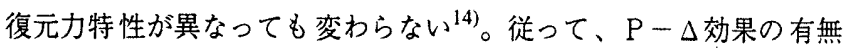
によって入力エネルギー量は変わらない。 $\mathrm{P}-\Delta$ 効果が塑性勾配が 非負であるBi-linear型のばね特性を有する振動系の応答に与える影 響は、塑性吸収エネルギーのひとつの方向への偏りと、それに伴う 塑性率の增大、並びに復元力を失うことによる崩壊の可能性である。

$\tau \geq 1$ のき、系は崩壊に至る可能性がある。

ここでは、 $0 \leq \tau \leq 1$ の場合を対象として、塑性歪エネルギーの一 方向への偏りとての関係並びに塑性率と $\tau$ の関係について、数值解 析結果に基づき検討する。

\section{2 解析条件}

ばねの荷重変形関係は鉄骨部 材の歪効果を考慮した履歴則 ${ }^{14)}$ に従うものとする。基線となる $x$ 軸で分けられる2つの領域に おいて $Q-x$ 関係は独立であり、 1つの領域における各履歴サイク ルの塑性の $Q-x$ を基線 $x$ 軸に 関して平行移動し順次つなぎ合 わせたものは単調加力下の $Q-x$ 関係に一致する、という

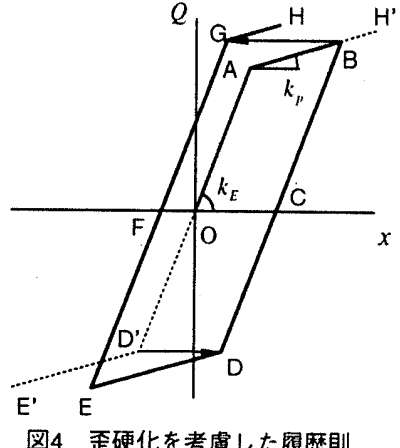

図4歪硬化を考慮した蕧歴則 もので、図4において、破線は単調加力下の $Q-x$ 関倸であり、1サ 

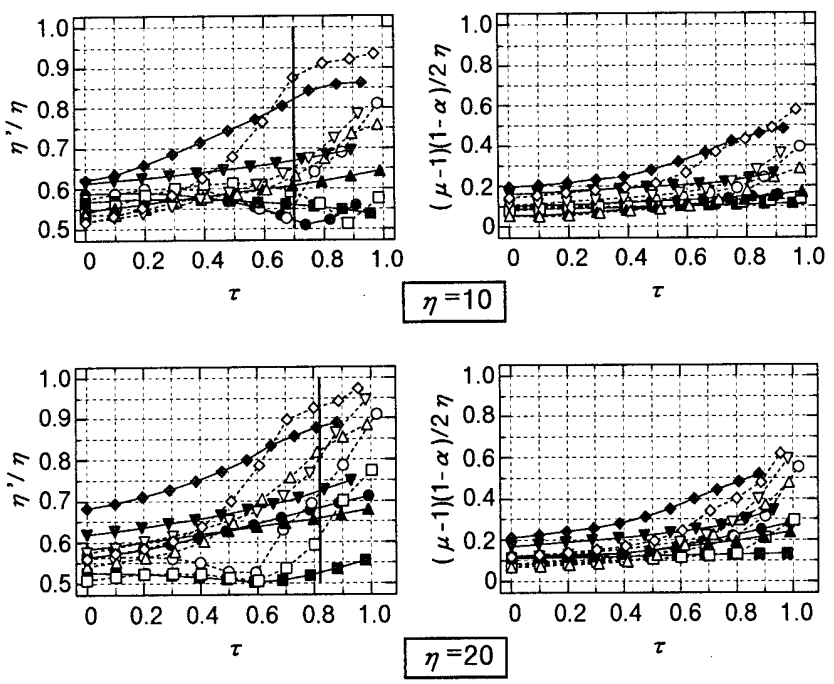

(1) EL CENTRO NS
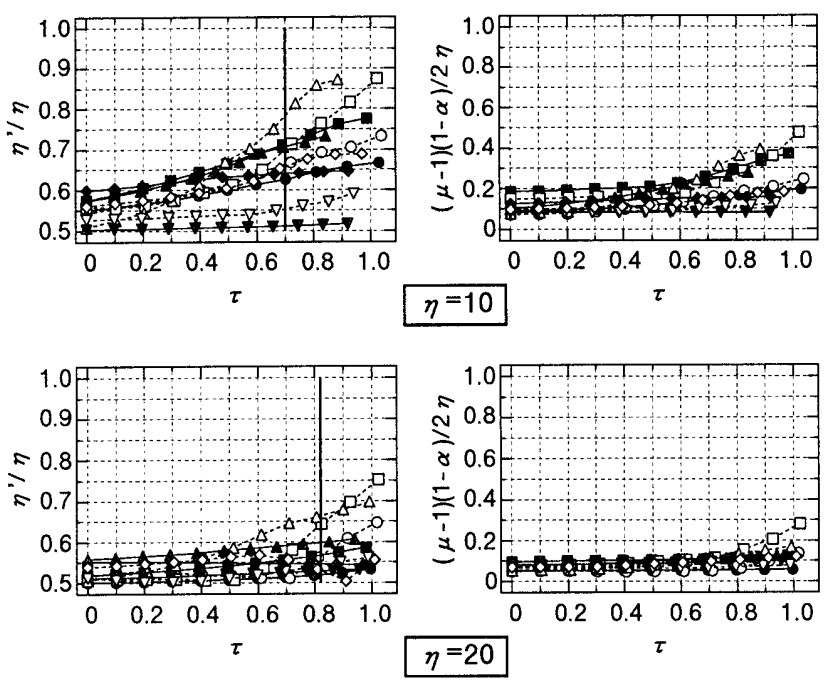

(3) HACHINOHE NS
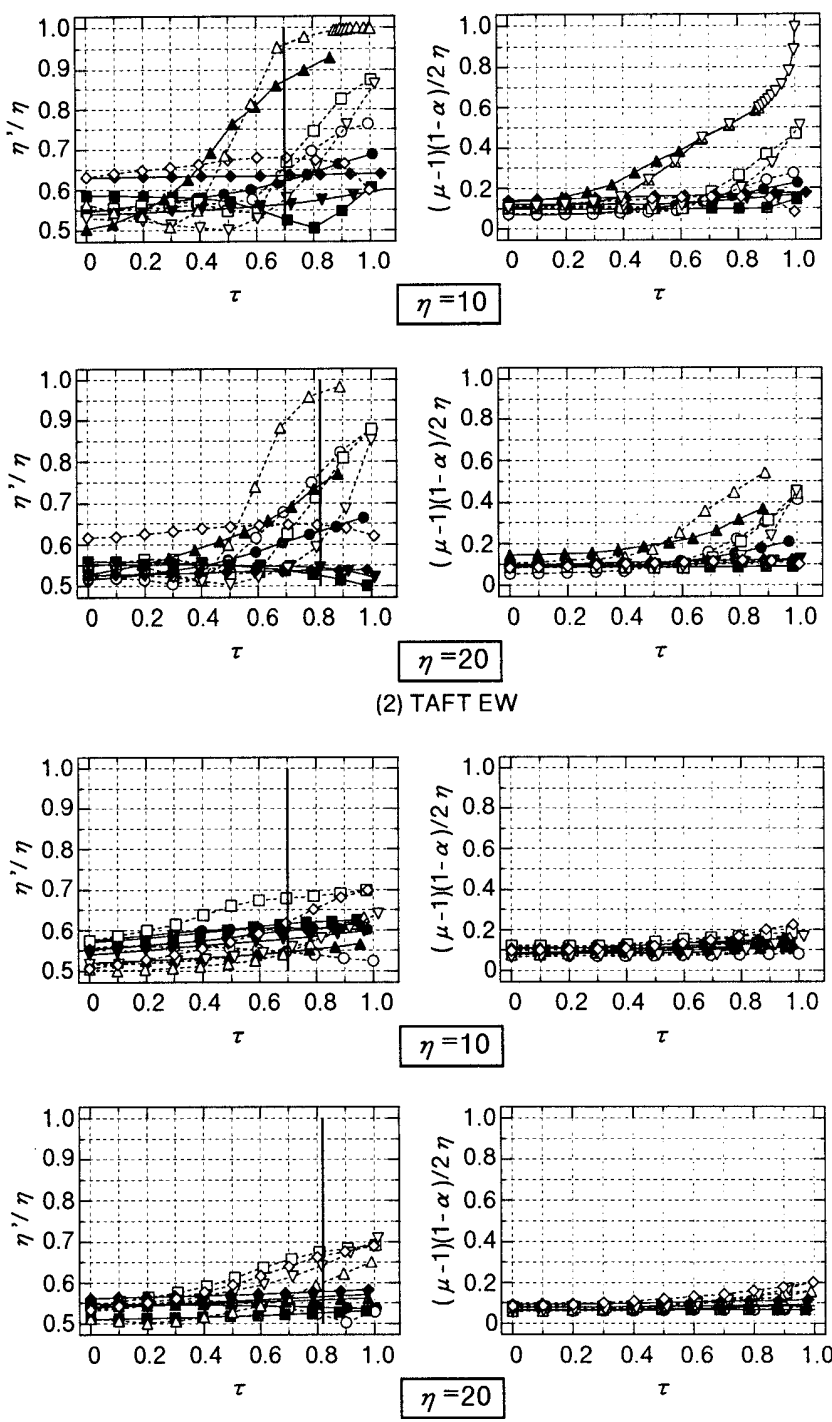

(4) JMA KOBE NS
イクル目のC-D-Eは $x$ 軸に平行に移動すれば単調加力下の $Q-x$ 関 倸におけるO-D'-E'と一致し、同様に2サイクル目のF-G-Hを $x$ 軸に平 行移動したものはC-B-Hと一致する。

塑性勾配係数 $\alpha$ （図2）は、 $0 \leq \alpha \leq 0.1$ と寸る。

固有周期（ $k_{p_{\Delta}}=0$ のとき）は、1,2,3,4,5secの5種類とし、減衰定 数は2\%とする。また、入力地震波は、EL CENTRO NS, TAFT EW, HACHINOHE NS, JMA KOBE NSの4波とし、入力の大きさは $\theta=0$ (すなわち $\left.k_{P \Delta}=0\right)$ のときの $\eta か ゙ 10$ と20となる様な2種類とする。 数值積分にはNew mark $\beta$ 法（ $\beta=0.25 ）$ を用い、積分時間間隔は

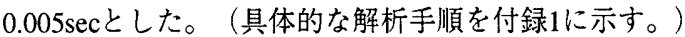

\section{3 解析結果}

解析結果を図5に示す。图5(1)〜(4)はそれぞれEL CENTRO，TAFT， HACHINOHE，JMA KOBE波に対する結果を示しており、全ての図 の横軸は安定比てである。図5(1)の4つの図のうち、上段は $\eta$ が10の 場合、下段が20の場合で、それぞれ左側はエネルギーの偏りを、右 側は塑性率を表している。四5(2)〜 (4)についても同様である。解析
值は固有周期 $1 〜 5 \sec に$ 対し、 $\alpha=0$ と $\alpha=0.1$ の場合についてプロッ トしている。

1) 歪エネルギーの偏り

エネルギーの偏りを示す図の縦軸は、正側あるいは負側で吸収し た歪エネルギーの大きい方 $\left(\eta^{\prime}\right)$ を全歪エネルギー（ $\eta$ ）で除した 值である。

\section{$\alpha=0$ の場合は、 $\tau>0$ に対} して復元力の塑性勾配は負と なる。四中の縦の実線は $\alpha=0.1$ で塑性勾配が負となら ない限界のてを示している。 応答結果より、歪エネルギー の偏りの程度は復元力特性の 塑性勾配の符号に支配される ものではないことが分かる。

図6は $\alpha=0.1$ 、固有周期 5sec、EL CENTRO、 $\eta=10$ の

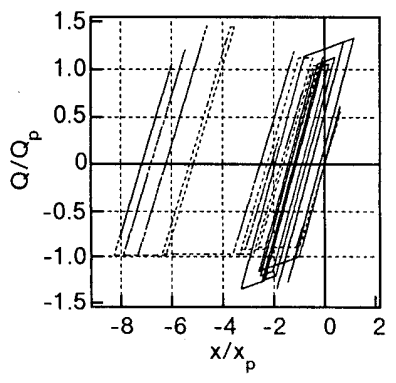

図6 Q-x関係 $\alpha=0.1 、 5 \mathrm{sec}$ 、 EL CENTRO、 $\eta=10$ 
場合について、 $\tau=0$ と $\tau=0.7$ 場合の応答を比較したものである。 いずれも復元力の 2 次勾配は正であるが、 $\tau=0.7$ の場合は歪エネル ギーの偏りが生じていることが分かる。

2) 望性率

図3のF点の変位 $x_{F}$ に対し、次式が成り立つ。

$$
\frac{x_{F}}{x_{p}}-1=\frac{1-\theta_{c r}}{\theta_{c r}-\alpha}
$$

上式の $\theta_{c r}$ に(7)式を代入すると、次式が導かれる。

$$
\frac{x_{F}}{x_{p}}-1=\frac{2 \eta}{1-\alpha}
$$

$x_{F} / x_{p}=\mu_{F}$ （図3F点の塑性率）とおくと、上式は次のように表さ れる。

$$
\frac{\left(\mu_{F}-1\right)(1-\alpha)}{2 \eta}=1
$$

塑性率を表す図においては、応答結果より塑性率 $\mu$ を求め、 $(\mu-1)(1-\alpha) / 2 \eta$ の值をプロットしている。図3のF点の場合は縦軸が 1 の值にプロットされる。

\section{3) 解析結果のまとめ}

図5より、同一の地震波に対しては、ての変化に対するエネルギー の偏りの程度の変化および塑性率の変化共に、入力の大きさが異なっ ても、また $\alpha$ が変化しても概ね等しいことが分かる。従って、ては $\mathrm{P}-\Delta$ 効果の影響を表す適切な指標である。

図5による歪エネルギーの偏りおよび塑性率に関するプロットを 重ねたものを図7に示す。 $P-\Delta$ 効果による歪エネルギーの偏りお よび塑性率の変化は、それぞれ下式により概ね安全側に推定するこ とができる。

歪エネルギーの偏り

$$
\frac{\eta^{\prime}}{\eta}=0.3 \tau+0.7
$$

塑性率

$$
\frac{(\mu-1)(1-\alpha)}{2 \eta}=0.8 \tau^{2}+0.2
$$

または、

$$
\mu=\frac{2 \eta\left(0.8 \tau^{2}+0.2\right)}{1-\alpha}+1
$$

ただし、 $0 \leq \alpha \leq 0.1$

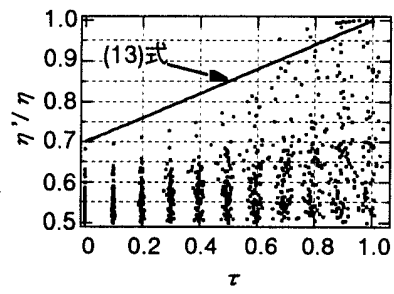

(a) 昰エネルギーの偏り

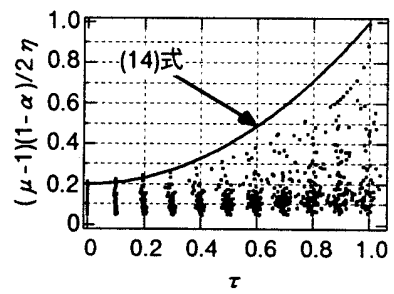

(b) 崩性率
図7 $\tau$ と $\eta^{\prime} / \eta$ および $(\mu-1)(1-\alpha) / 2 \eta$ の関係

\subsection{Bernalの推定式との比較}

Bernalは、完全弾塑性型の復元力特性を有する1質点系モデルに対 し、予め設定した塑性率となる降伏せん断力を $\mathrm{P}-\Delta$ 効果を考慮し た場合と考慮しない場合について求め、その比を増大率と定義し、
増大率についての推定式を提案している゙。

本研究では降伏耐力を一定としたときの $\mathrm{P}$ 一 $\Delta$ 効果による塑性率 の変化を求めているので、この結果を用いて、Bernalの定義してい る降伏耐力増大率を導き、Bernalの推定式との比較を行う。

設定した $\mu$ に対し、P $-\Delta$ 効果を無視した場合の $\eta$ を $\eta_{0} 、 P-\Delta$ 効果を考慮した場合の $\eta$ を $\eta_{P \Delta}$ とすれば、(14)、(9)式より次式が導 かれる。

$$
\begin{aligned}
& \frac{(\mu-1)(1-\alpha)}{2 \eta_{0}}=0.2 \\
& \frac{(\mu-1)(1-\alpha)}{2 \eta_{P \Delta}}=0.8\left\{\frac{\theta\left(2 \eta_{P \Delta}+1-\alpha\right)}{2 \eta_{P \Delta} \alpha+1-\alpha}\right\}^{2}+0.2
\end{aligned}
$$

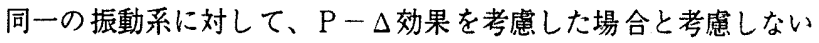
場合について応答の塑性率が同じであれば、最大変位点はそれぞれ 図8にA、Bで示す様な関係となり、それぞれの入力の大きさ $\eta_{0}$ 、 $\eta_{P \Delta}$ は(15)、(16)式を満足する。次にこの系の降伏耐力を $\mathrm{a}$ 倍し、 $\eta_{0}$ と同じ入力に対する $\mathrm{P}-\Delta$ 効果を考慮した応答の塑性率が $\mu$ である とすれば、最大变位点は図8に示すCで示す様な位置となる。このと きの応答は、変位及び復元力共に上記の最大変位点がAとなる応答 の $\mathrm{a}$ 倍になっているので、それぞれの歪エネルギーの比の平方根が aに等しい。すなわち、

$$
\mathrm{a}=\sqrt{\frac{\eta_{0}}{\eta_{p \Delta}}}
$$

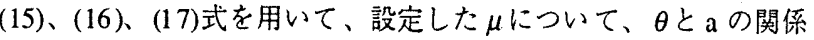
を求めることができる。

Bernalは、地震応答解析結果に基づき増大率 $\mathrm{a}$ の推定式として次 式を提案している。

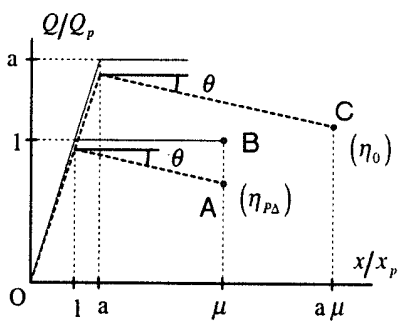

図8 $\quad P-\Delta$ 効果考慮の有無による応答変位の違い
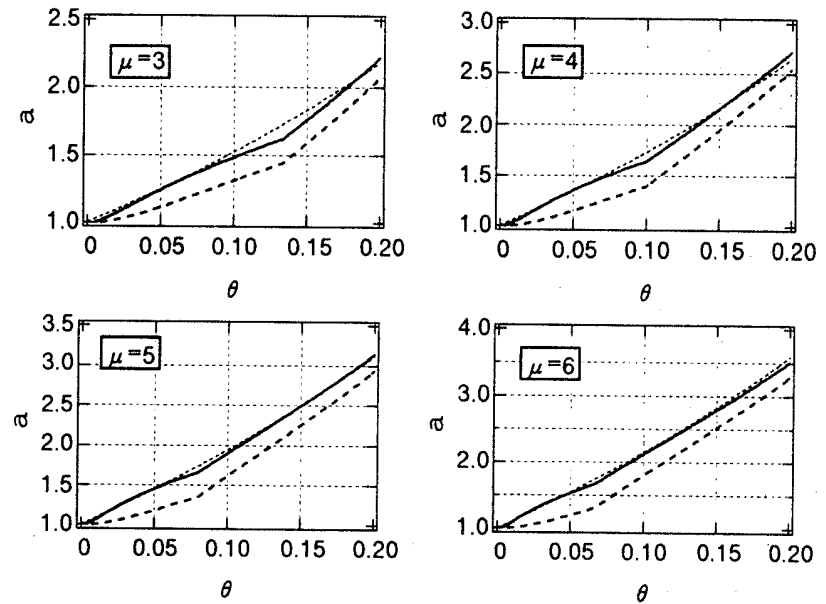

図9 $\theta$ と降伏耐力增大率 $\mathrm{a}$ の関係 


$$
\mathrm{a}=\frac{1+\gamma \theta}{1-\theta} \quad \gamma=1.87(\mu-1)
$$

なお、Bernalは次式で定める $\theta$ の值を $\theta$ の限界值としている。

$$
\theta=\frac{1}{\lambda \mu} \quad \lambda=2.5
$$

限界值を越えた範囲については、入力エネルギーの変化に対する 応答変位の変動が大きいことを考慮して、P $\mathrm{P}$ - $\Delta$ 効果を考慮しない ときの塑性率は $\mu 、 \mathrm{P}-\Delta$ 効果を考慮したときの塑性率は $1 /(\lambda \theta)$ と して増大率を定めているので、本研究においてもそれに従って増大 率を求める。

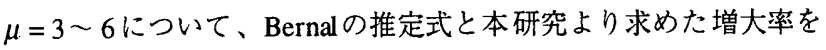
図9に示す。Bernalの研究では $\alpha=0$ の場合のみを対象としているが、 本研究では $\alpha$ はに限らないので、本研究結果は $\alpha=0$ と $\alpha=0.1$ の 場合を示している。

増大率 $\mathrm{a}$ に対するBernalの推定式と $\alpha=0$ のときの本研究結果とは よく一致している。また、 $\alpha>0$ のときの増大率は、 $\alpha=0$ のときの 増大率より小さいことが分かる。

\section{4. せん断型多質点系モデルに対する解析}

\section{1 第1層の安定比}

$\mathrm{P}-\Delta$ 効果の影響は建物下層部が大きいと考えられるので、せん 断型多質点系の第1層における安定比について考える。層の復元力 特性は1質点系の場合と同じとする。

第1層の安定係数 $\theta_{1}$ は次式で与えられる。

$$
\theta_{1}=\frac{k_{P A 1}}{k_{E 1}}
$$

ここで、

$k_{E 1}$ : 第1層の弾性剛性、 $k_{P \Delta 1}=m g / l 、 m$ : 建物総質量、 $l:$ 第 1 層の階高

第1層の $\theta_{c c}$ は、(7)式より得られる。

$$
\theta_{c r 1}=\frac{2 \eta_{1} \alpha+1-\alpha}{2 \eta_{1}+1-\alpha}
$$

ここで、 $\eta_{1}$ は第1層で吸収するエネルギーについての無次元量で、 次式で定められる。

$$
\eta_{1}=\frac{E_{D 1}}{Q_{p 1} x_{p 1}}
$$

ここで、

$E_{D 1}$ : 第1層で吸収する歪エネルギー、 $Q_{p 1}, x_{p 1}$ ：第1層の降伏せ 几断力、降伏変位

(20)、(21)式を用いて、第1層の安定比 $\tau_{1}$ を求めることができる。

$$
\tau_{1}=\theta_{1} / \theta_{c r 1}
$$

(21)式による $\eta_{1}$ は、(11)式で与えられる全歪エネルギーの無次元 表示である $\eta$ とは一般に異なった值となる。次に $\eta_{1}$ と $\eta$ の関係及び 安定比の有効性について検討する。

\section{2 単純化した建物モデルに対する検討} 次の様な建物モデルを考える（図10）。

・1次固有振動モードは直線とする。

・高さ方向の質量分布は一定とする。
・固有周期 $T(\mathrm{sec})$ と高さ $H(\mathrm{~m})$ の関係、 固有周期と層数 $N$ の関係は以下とする。

$$
T=0.025 H
$$$$
T=0.1 N
$$

このモデルに対する安定倸数 $\theta_{1}$ を求め る。

基礎位置の転倒モーメント $M_{1}$ と層間 変形角 $\varphi$ の関係を、

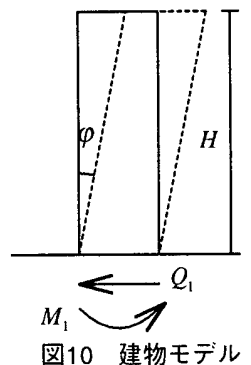

$$
M_{1}=K \varphi
$$

とする。基礎位置における質量慣性2次モーメントIは総質量を $m$ 、高さを $H$ とすれば、

$$
I=m H^{2} / 3
$$

であるから、固有周期 $T$ は次式で与えられる。

$$
T=2 \pi \sqrt{\frac{I}{K}}=2 \pi \sqrt{\frac{m H^{2}}{3 K}}
$$

第1層のせん断力を $Q_{1}$ とすれば、 $Q_{1}$ と $M_{1}$ の関係は、

$$
Q_{1}=\frac{3}{2 H} M_{1}
$$

であるから、(25)、(26)、(27)式より、

$$
Q_{1}=\frac{2 \pi^{2} H m}{T^{2}} \varphi
$$

となる。第1層の弾性剛性 $k_{E 1}$ は、第1層の層間変位が $\varphi l$ であるから、 次式で与えられる。

$$
k_{E}=\frac{Q_{1}}{\varphi l}=\frac{2 \pi^{2} H m}{T^{2} l}
$$

第1層の $\mathrm{P}-\Delta$ 剛性 $k_{P \Delta 1}$ は、

$$
k_{P \Delta 1}=\frac{m g}{l}
$$

であるから、(29)式を用いれば、 $\theta_{1}$ は次式で表される。

$$
\theta_{1}=\frac{k_{P \Delta 1}}{k_{E 1}}=\frac{g T^{2}}{2 \pi^{2} H}
$$

次に、 $\eta_{1}$ と $\eta$ の関係を求める。

文献15)によると、多層建物の場合の層のエネルギー集中を考慮す ると、建物全体で吸収する歪エネルギー $E_{D}$ と第1層で吸収する歪工 ネルギー $E_{D 1}$ の関係は、弾性エネルギーを無視すると、復元力特性 が完全弾塑性型の場合、次式で表される。

$$
E_{D}=\gamma_{1} E_{D 1}
$$

$\gamma_{1}$ は次式で与えられる。

$$
\gamma_{1}=1+0.64(N-1) p_{d}^{-n}
$$

ここで、

$$
\begin{aligned}
& p_{d}=1.185-0.0014 N \\
& n=12
\end{aligned}
$$

$15 \leq N \leq 50$ の場合、上式で $\gamma_{1}$ を求めると、ほぼ次式の值となる。

$$
\gamma_{1}=0.16 \mathrm{~N}
$$

(10)、(11)式より $V_{D}$ を消去すると、次式が得られる。 


$$
E_{D}=\frac{\left(m g C_{B}\right)^{2} \eta}{(2 \pi / T)^{2} m}
$$

一方、第1層の降伏耐力を $Q_{p 1}$ とすれば、 $E_{D 1}$ は次式で与えられる。

$$
E_{D 1}=\frac{Q_{p 1}^{2}}{k_{E 1}} \cdot \eta_{1}
$$

$Q_{p 1}=m g C_{B}$ であるから、(29)式を用いれば、(34)式は次式に書き換 えられる。

$$
E_{D 1}=\frac{\left(m g C_{B}\right)^{2} T^{2} l}{2 \pi^{2} H m} \cdot \eta_{1}
$$

(31)、(33)、(35)式より、

$$
\eta=\gamma_{1} \frac{2}{H / l} \eta_{1}
$$

$H / l=N$ であるから、(32)式を用いれば、次式が得られる。

$$
\eta_{1}=\frac{\eta}{2 \times 0.16}=3 \eta
$$

\section{3 応答解析 \\ (1) 解析モデル}

応答解析に用いたモデルの概要は以下である。

- $N=50 、 T=5(\mathrm{sec}) 、 H=200(\mathrm{~m}) 、 l=4(\mathrm{~m})$ とする。

·質量分布は均等とする。

・水平剛性分布は直線分布とし、最上層と最下層の剛性の比は1:3と する。

·各層の降伏せん断力の分布は耐震規定のAi分布とする。

・減衰は剛性比例型とし、1次振動に対する減衰定数は $2 \%$ とする。 その他については、1質点系モデルの場合と同様である。

\section{(2) 解析結果}

a) $\eta_{1}$ と $\eta$ の関係

EL CENTRO波及びTAFT波を用い、 $\eta=10$ の入力に対して行った 解析結果より求めた $\eta_{1} / \eta$ を図11に示す。プロットが無いのは崩壊し た場合である。予想されるように、 $\alpha$ が大きくなると $\eta_{1} / \eta$ は小さく なる傾向がある。 $\alpha=0$ の応答結果は概ね(37)式と対応している。

図11に示す結果から、ここに示した解析モデルの場合、 $\eta_{1} / \eta$ と $\alpha$ の間には近似的に次式が成り立つ。

$$
\frac{\eta_{1}}{\eta}=3-15 \alpha
$$

$\eta_{1} / \eta$ は $\alpha=0$ とすれば安全側の値となり、文献15)の方法で推定する ことができる。

b) 安定比

(38)式を用いて、 $\alpha$ と安定比の関係を求めると図12の様になる。 図12より、 $\alpha<0.05$ では $\tau$ は1を越えており、 $\alpha=0.05$ では $\tau$ はほほ $1 、 \alpha=0.1$ では $\tau$ は約 0.5 である。

図 13 は $\eta=10$ の入力に対する応答から求めた各層の累積塑性変形 倍率の分布を示したものである。プロットがないのは崩壊した場合 である。 $\tau \geq 1 の$ 場合は崩壊していることが分かる。

EL CENTRO地震動の場合について、第1層に関する $\tau$ と $\eta_{1}^{\prime} / \eta_{1} お$ よび $\tau$ と $\left(\mu_{1}-1\right)(1-\alpha) / 2 \eta_{1}$ の関係を図14に示す。

図14の結果は図7と類似の結果であり、安定比は、せん断型多質 点系モデルの場合についても $\mathrm{P}-\Delta$ 効果を示寸指標として有効であ
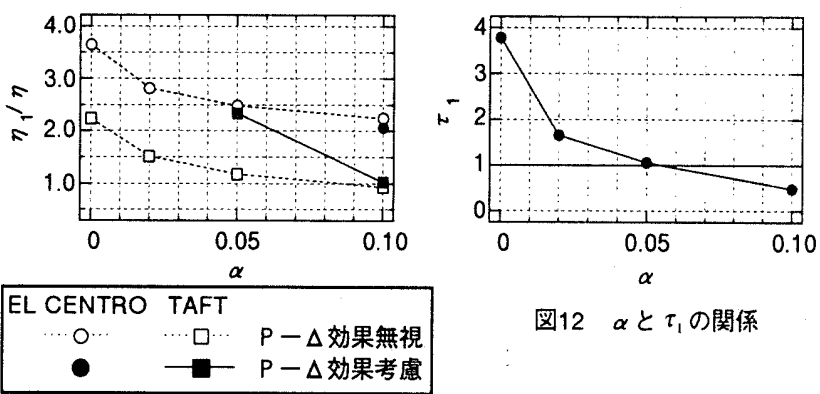

図12 $\alpha$ と $\tau_{1}$ の関係

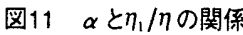
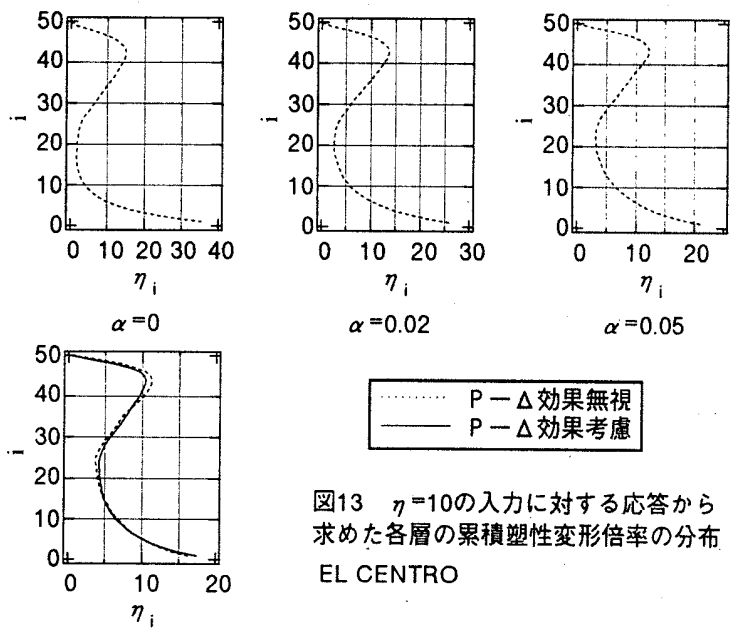

$\alpha=0.02$

$\alpha=0.05$

$\alpha=0.1$
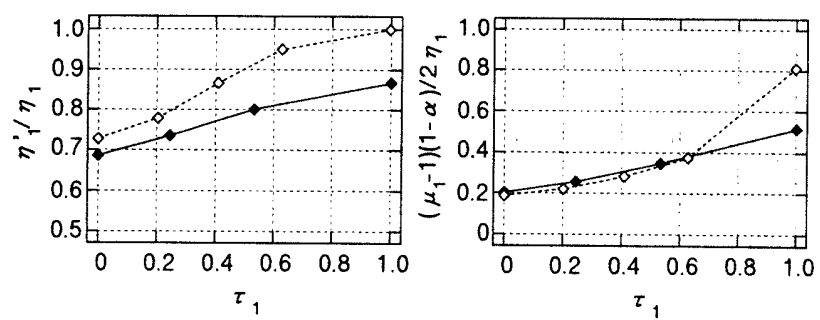

図14 第1層の安定比と歪エネルギーの 偏りおよび塑性率の関係

図13 $\eta=10$ の入に対する応答から 求めた各層の累積塑性変形倍率の分布 EL CENTRO

ることが分かる。

\section{5. 梁降伏型骨組モデルに対する解析}

梁降伏型骨組の地震時の動的崩壊過程における変形集中現象が上 谷により指摘されている。

上谷は、変形が集中する高さを予測する理論を示し ${ }^{10)} 、$ 地震応答 解析結果との対応を確認している ${ }^{11)}$ 。

上谷の理論により、変形集中領域については明らかにされたが、 入力地震動の大きさとこの様な不安定崩壊が発生する条件との関係 が不明である。本研究では、安定比を用い、入力の大きさと変形集 中現象による変形量および崩壊との関係について検討する。

\section{1 変形集中領域における安定比}

図15(a)に示す様な1本の柱と両側の梁から成るモデルを用いる。 柱は降伏しないものとする。

変形集中領域の層数は文献11)によれば次式を満足する最小の $n_{h}$ 

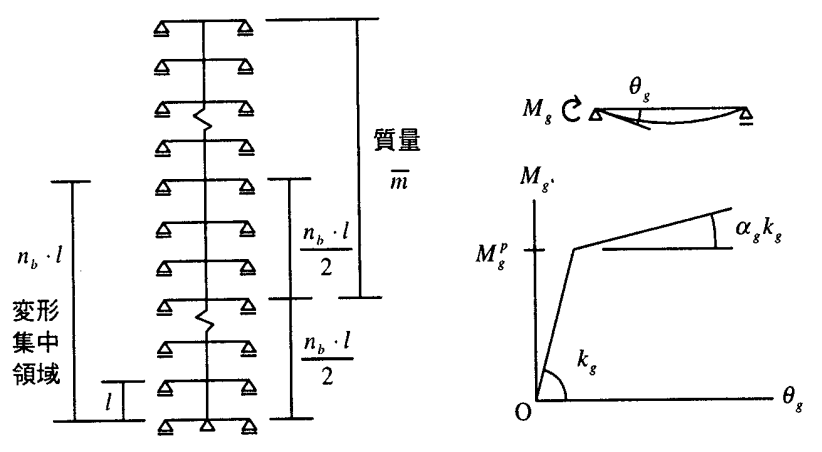

(a) 検討用モデル

(b) 梁の材端モーメントと回転角の関係

図15梁降伏型骨組モデル

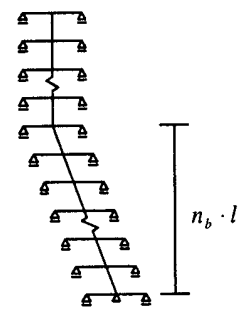

図16 变形モード

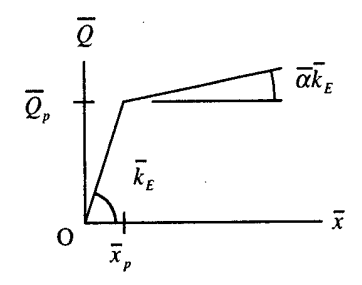

図17 代表層の荷重变形関係

( $\mathrm{P}-\Delta$ 効果を考慮しないとき)
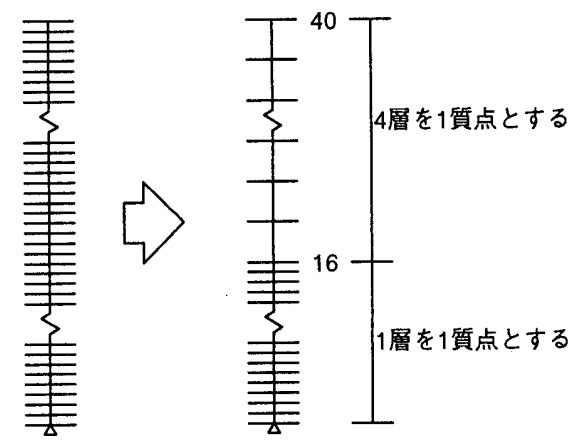

図18 骨組の置換

である。

$$
\bar{m} g \geq \frac{\pi^{2} E I_{c}}{\left(n_{b} \cdot l\right)^{2}}+\frac{2 \alpha_{g} k_{g}}{l}
$$

ここで、

$E I_{c}$ : 柱の曲げ岡性、 $\alpha_{s} k_{s}$ : 梁の降伏後の $d M_{s} / d \theta_{s} \quad$ （図15(b)参

照）、 $\bar{m}: n_{b} / 2$ 層から頂部までの質量の総和

変形モードを図16の様に折れ線で仮定する。代表層の荷重変形関 係は図17の様であるとする。代表層の復元力および $\mathrm{P}-\Delta$ 効果剛性 $\left(\bar{k}_{P \Delta}\right)$ はそ狄ぞれ第1層から第 $n_{b}$ 層までの復元力および $\mathrm{P}-\Delta$ 効果 剛性の平均値とする。

代表層の安定係数 $\bar{\theta}$ は次式で定められる。

$$
\bar{\theta}=\bar{k}_{P \Delta} / \bar{k}_{E}
$$

変形集中領域で吸収する歪エネルギー $\bar{E}_{D}$ の系全体で吸収する歪 エネルギー $E_{D}$ に対する比を $\xi$ とる。

$$
\bar{E}_{D}=\xi E_{D}
$$

代表層の累積塑性変形倍率 $\bar{\eta} は 、 \bar{E}_{D}$ を用いて次式で表される。

$$
\bar{\eta}=\frac{\bar{E}_{D}}{n_{b} \bar{Q}_{p}^{2} / \bar{k}_{E}}
$$

(10)、(41)、(42)式より、可は次のように書ける。

$$
\bar{\eta}=\frac{m \bar{k}_{k} \xi}{2 n_{b} \bar{Q}_{p}^{2}} V_{D}^{2}
$$

代表層について、塑性勾配係数 $\bar{\alpha}$ （図17参照）、(40)式による安 定係数 $\bar{\theta} 、(43)$ 式による $\bar{\eta}$ をそれぞれ(9)式の $\alpha 、 \theta 、 \eta に$ 代入す れば、変形集中領域における安定比 $\bar{\tau} か ゙$ 定まる。

\section{2 応答解析 \\ (1) 解析モデル}

40層の梁降伏型骨組を対象として応答解析を行う。解析において、 $\mathrm{P}-\Delta$ 効果は層レベルで考虑している。全ての柱扔よび全ての梁の 断面はそれぞれ同一とする。解析骨組は16層以下は1層を1質点とし、 変形集中が生じない16層以上は4層を1質点とする様な集約モデルと した（図18参照）。質量分布は均等とし、梁の塑性勾配係数 $\alpha_{\mathrm{g}}$ （図 15(b)参照) は0とした。入力地震波として、EL CENTRO NS波を用 いた。

(39)式を満たす最小の $n_{b}$ の值は以下である。

$$
n_{b}=11
$$

(2) 解析結果

応答時の骨組全体の変形を図19に示す。図19は $\bar{\tau}=0.94$ の場合に

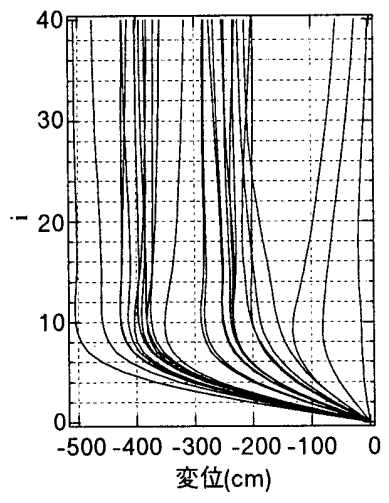

図19 骨組全体の2秒毎の变形 $(\bar{\tau}=0.94)$

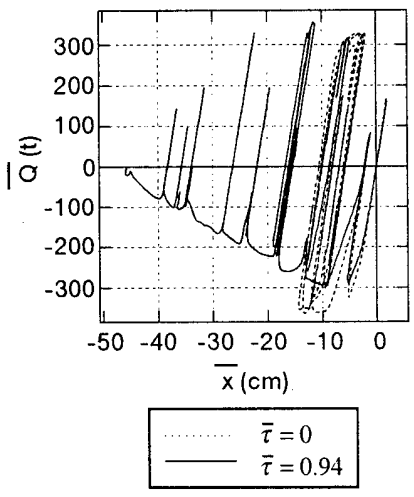

図20 代表層の荷重変形関係

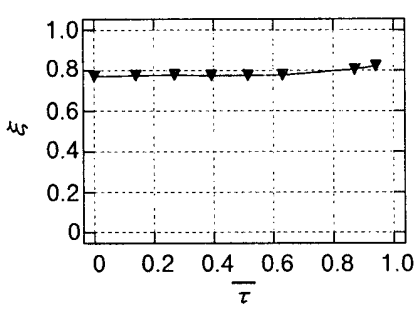

図21 代表層の安定比と
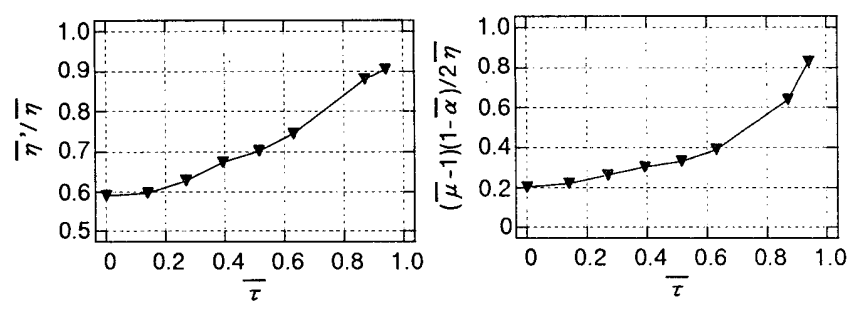

図22代表層の安定比と稆エネルギー の偏りおよび塑性率の関係 
ついて、2秒毎の変形を画いている。

応答による代表層の層せん断力 $(\bar{Q})$ 、層間変位 $(\bar{x})$ は、第1 層から第 $n_{b}$ 層までの刻々の応答せん断力、応答層間変位の平均值よ り求めた。 $\bar{\tau}=0$ および $\bar{\tau}=0.94$ の場合について、 $\bar{x}$ と $\bar{Q}$ の関係を 図20に示す。

図21は応答結果より求めた $\bar{\tau}$ との関係である。この振動系にお

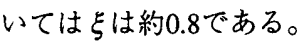

代表層の応答結果より求めた $\bar{\tau}$ と $\bar{\eta}^{\prime} / \bar{\eta}$ 扔よび $\bar{\tau}$ と

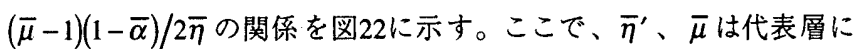

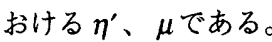

図22の結果は図7に示す結果と類似であり、安定比が梁降伏型骨 組の変形集中現象に対しても有効な指標であることが分かる。

架構が与えられたとき、 $n_{b}$ と共に予め $\xi$ を推定することができれ ば、想定した地震入力 $\left(V_{D}\right)$ に対して(43)式を用いて安定比が定ま る。安定比を用いて、変形集中領域における歪エネルギーの一方向 への偏りと塑性率を予測することができる。乡の推定法を検討する ことは今後の課題である。 $\xi=1$ とすれば、安全側の予測が得られる。

\section{6. 結論}

弾塑性地震応答における $\mathrm{P}-\Delta$ 効果の影響を表す指標として安定 比 $\tau$ を導入した。安定比は振動系の特性と入力の大きさとを含む指 標で、 $\tau$ を用いることにより $\mathrm{P}-\Delta$ 効果を考慮した歪エネルギーの ひとつの方向への偏りおよひ塑性率について予測することができる。

1 質点系モデル、せん断型多質点系モデル、梁降伏型骨組モデル に対して応答解析を行い、安定比の有効性を検証した。

\section{参考文献}

1) Bernal, D. :Amplification Factor for Inelastic Dynamic $P-\Delta$ Effects in Earthquake Analysis, Earthquake Engineering and Structural Dynamics, Vol.15, pp.635-651, 1987

2）曾我部博之, 小高昭夫:強震を受ける弾塑性質点系の $\mathrm{P}-\Delta$ 効果について, 日本建築学会構造系論文集，第463号，pp.19-26，1994年9月

3）秋山宏: 鋼構造剛接骨組の耐震性に拉よほす $\mathrm{P}-\Delta$ 効果の影響，日本建築 学会論文報告集, 第340号, pp.11-16，1984年6月

4) 文雪峰, 鈴木計夫他 2 名:低層部にソフトストーリーを有するコンクリー 卜多層骨組構造の不安定予測（その1）安定限界の誘導，日本建築学会大 会学術講演梗概集，構造 I，pp.431-432，1993年9月

5）蘇道遠，鈴木計夫他 2 名:低層部にソフトストーリーを有するコンクリー 卜多層骨組構造の不安定予測（その2）動的解析による検証，日本建築学 会大会学術講演梗概集，構造 I, pp.433-434，1993年9月

6) 河上勝博, 石山鿆二:耐震設計における構造特性係数の最小値（その1） 解析方法と結果, 日本建築学会大会学術講演梗概集, 構造 I, pp.67$68 ， 1994$ 年9月

7) 石山祐二, 河上勝博:耐震設計における構造特性係数の最小値（その2) ベースシヤー係数スペクトルの考察, 日本建筑学会大会学術溝演梗概集, 構造 I, pp.69-70, 1994年9月

8）板矢崇志，松島豊:高層建築物の地震応答における $P-\Delta$ 効果，日本建築 学会大会学術講演梗概集, 構造 $\square, p p .685-686,1995$ 年8月
9）板矢崇志, 松島豊: $P-\Delta$ 効果を考慮した高層建築物の弾塑性地霞応答, 日本建筑学会大会学術講演梗概集，構造 II，pp.495-496，1996年9月

10）上谷宏二:繰返し水平載荷を受ける多層多スパン平面骨組の塑性崩壊挙動 （その1）多層多スパン平面骨組の对称限界理論，日本建築学会構造系論 文集，第435号，pp.61-70，1992年5月

11）上谷宏二, 田川浩:梁降伏型骨組の動的崩壊過程における変形集中現象, 日本建筑学会構造系論文集，第483号，pp.51-60，1996年5月

12) Sun, C. K. , Berg, G. V. and Hanson, R. D. :Gravity Effects on Single-Degree Inelastic System, ASCE Vol.99, No.EM1, pp.183-200, February 1973.

13) Applied Technology Council :Tentative Provisions for the Development of Seismic Regulations for Buildings, National Bereau Standards, 1978

14）秋山宏:建筑物の酎震極限設計 第2版, 東京大学出版会, 1987年

15）日本建築学会: 建築耐震設計における保有水平酎力と变形性能 (1990)，1990年10月

\section{付録1 1質点系モデルの解析手順}

具体的な解析手順を以下に示す。

減衰定数は $2 \%$ とする。 $m$ を設定する。

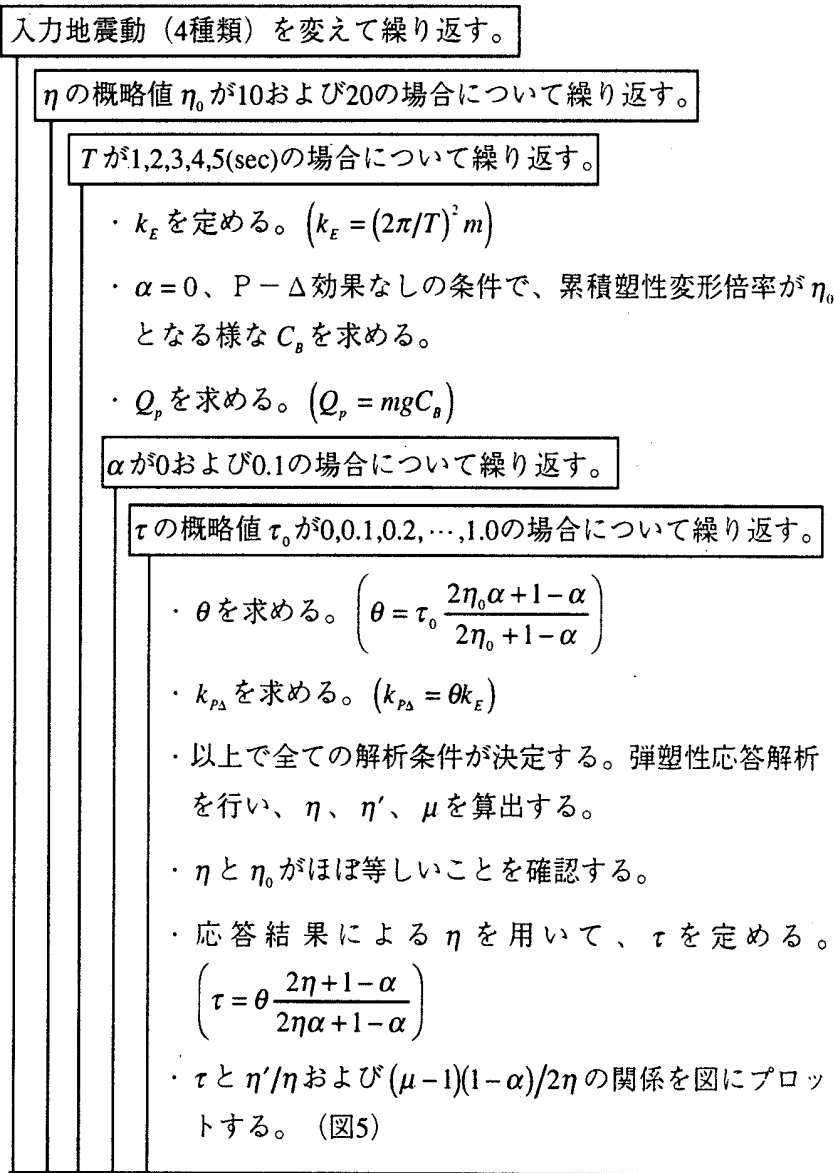

$m$ 抢よび入力地震動の大きさはそれぞれどの様に設定しても図5の プロットは変わらないので、任意の值に設定してよい。また、図5 にロで示す $\eta$ は、上記の $\eta_{0}$ である。 